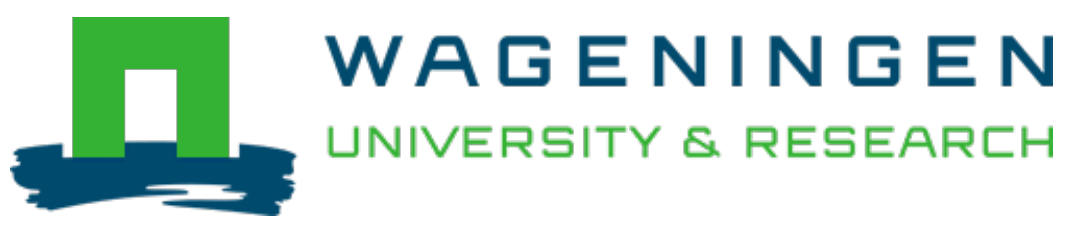

\title{
Inactivation of bacterial pathogens in yoba mutandabota, a dairy product fermented with the probiotic Lactobacillus rhamnosus yoba
}

\author{
International Journal of Food Microbiology
}

Mpofu, A.; Linnemann, A.R.; Nout, M.J.R.; Zwietering, M.H.; Smid, E.J. et al

https://doi.org/10.1016/j.ijfoodmicro.2015.09.016

This publication is made publicly available in the institutional repository of Wageningen University and Research, under the terms of article $25 \mathrm{fa}$ of the Dutch Copyright Act, also known as the Amendment Taverne. This has been done with explicit consent by the author.

Article 25 fa states that the author of a short scientific work funded either wholly or partially by Dutch public funds is entitled to make that work publicly available for no consideration following a reasonable period of time after the work was first published, provided that clear reference is made to the source of the first publication of the work.

This publication is distributed under The Association of Universities in the Netherlands (VSNU) 'Article $25 \mathrm{fa}$ implementation' project. In this project research outputs of researchers employed by Dutch Universities that comply with the legal requirements of Article $25 \mathrm{fa}$ of the Dutch Copyright Act are distributed online and free of cost or other barriers in institutional repositories. Research outputs are distributed six months after their first online publication in the original published version and with proper attribution to the source of the original publication.

You are permitted to download and use the publication for personal purposes. All rights remain with the author(s) and / or copyright owner(s) of this work. Any use of the publication or parts of it other than authorised under article $25 \mathrm{fa}$ of the Dutch Copyright act is prohibited. Wageningen University \& Research and the author(s) of this publication shall not be held responsible or liable for any damages resulting from your (re)use of this publication.

For questions regarding the public availability of this publication please contact openscience.library@wur.nl 


\title{
Inactivation of bacterial pathogens in yoba mutandabota, a dairy product fermented with the probiotic Lactobacillus rhamnosus yoba
}

\author{
Augustine Mpofu a,b,c Anita R. Linnemann ${ }^{\mathrm{c}}$, Martinus J.R. Nout ${ }^{\mathrm{b}}$, Marcel H. Zwietering ${ }^{\mathrm{b}}$, \\ Eddy J. Smid ${ }^{\mathrm{b}}$, Heidy M.W. den Besten ${ }^{\mathrm{b}, *}$ \\ a Department of Food Science and Technology, Chinhoyi University of Technology, P. Bag 7724 Chinhoyi, Zimbabwe \\ b Laboratory of Food Microbiology, Wageningen University, P.O. Box 17, 6700AA Wageningen, The Netherlands \\ c Food Quality and Design, Wageningen University, P.O. Box 17, 6700AA Wageningen, The Netherlands
}

\section{A R T I C L E I N F O}

\section{Article history:}

Received 24 April 2015

Received in revised form 11 September 2015

Accepted 26 September 2015

Available online xxxx

\section{Keywords:}

Food-borne infection

Challenge test

Fermentation

Survival

Baobab fruit

LGG

\begin{abstract}
A B S T R A C T
Mutandabota is a dairy product consumed as a major source of proteins and micronutrients in Southern Africa. In this study the microbial safety of traditional and a variant of mutandabota fermented with the probiotic Lactobacillus rhamnosus yoba (yoba mutandabota) was investigated by challenging the products with five important food pathogens: Listeria monocytogenes, Salmonella spp., Campylobacter jejuni, Escherichia coli 0157:H7 and Bacillus cereus. Pasteurized full-fat cow's milk was used for producing traditional and yoba mutandabota, and was inoculated with a cocktail of strains of the pathogens at an inoculum level of $5.5 \log \mathrm{cfu} / \mathrm{mL}$. Survival of the pathogens was monitored over a potential consumption time of $24 \mathrm{~h}$ for traditional mutandabota, and over $24 \mathrm{~h}$ of fermentation followed by $24 \mathrm{~h}$ of potential consumption time for yoba mutandabota. In traditional mutandabota ( $\mathrm{pH} 3.4 \pm 0.1$ ) no viable cells of $B$. cereus and C. jejuni were detected $3 \mathrm{~h}$ after inoculation, while L. monocytogenes, E. coli 0157:H7 and Salmonella spp. significantly declined $(\mathrm{P}<0.05)$, but could still be detected $(<3.5 \log$ inactivation $)$ at the end of the potential consumption time. This indicated that consumption of traditional mutandabota exposes consumers to the risk of food-borne microbial infections. In yoba mutandabota, L. rhamnosus yoba grew from $5.5 \pm 0.1 \log \mathrm{cfu} / \mathrm{mL}$ to $9.1 \pm 0.4 \log \mathrm{cfu} / \mathrm{mL}$ in the presence of pathogens. The $\mathrm{pH}$ of yoba mutandabota dropped from $4.2 \pm 0.1$ to $3.3 \pm 0.1$ after $24 \mathrm{~h}$ of fermentation, mainly due to organic acids produced during fermentation. Only Salmonella spp. was able to grow in yoba mutandabota during the first $9 \mathrm{~h}$ of fermentation, but then decreased in viable plate count. None of the tested pathogens were detected ( $>3.5 \log$ inactivation) after $3 \mathrm{~h}$ into potential consumption time of yoba mutandabota. Inactivation of pathogens in mutandabota is of public health significance because food-borne pathogens endanger public health upon consumption of contaminated food, especially in Southern Africa where there are many vulnerable consumers of mutandabota such as children, elderly and immuno-compromised people with HIV/AIDS. The findings of this study demonstrate that mutandabota fermented with L. rhamnosus yoba has antimicrobial properties against the tested pathogens and it is safer compared to the traditional mutandabota.
\end{abstract}

(c) 2015 Elsevier B.V. All rights reserved.

\section{Introduction}

Probiotic bacteria and their health effects are a focus of international food research. Incorporation of selected strains of the genera Bifidobacterium and Lactobacillus in milk products and lately in nondairy products has been studied in detail (McMaster et al., 2005; Østlie et al., 2003; Van Tienen et al., 2011). The beneficial effects of probiotic strains on the host and their mechanism of action have also been demonstrated quite well (Guandalini et al., 2000; Kankainen et al., 2009; von Ossowski et al., 2010). However, little information is available on the survival and growth of pathogens in dairy foods containing probiotic bacteria. Not only good survival of the probiotic bacteria in food

\footnotetext{
* Corresponding author.

E-mail address: heidy.denbesten@wur.nl (H.M.W. den Besten).
}

products during their specified shelf life is essential, but also the potential antimicrobial action of the probiotic bacteria against contaminating pathogens during the production process and shelf life is relevant.

Mutandabota is a non-fermented, milk-based food consumed daily as a major source of proteins and micronutrients, and it is also sometimes used as a weaning food for infants in Southern Africa (Zimbabwe Ministry of Agriculture, 2001). The product is made by mixing raw cow's or goat's milk 79\% (wt/wt), dry baobab (Adansonia digitata $\mathrm{L}$.) fruit pulp 14\% (wt/wt) and sugar 7\% (wt/wt) (Mpofu et al., 2014a). Mutandabota has a thick, yoghurt-like consistency, a sour taste and a $\mathrm{pH}$ of $3.4 \pm 0.1$. Generally, low $\mathrm{pH}$ products are regarded as microbiologically stable and safe to eat (ICMSF, 2002). However, observations on preparation of traditional mutandabota evoked questions about its potential role as a vehicle for food-borne microbial infections. The traditional method utilizes raw milk, which raises a food safety concern since 
the milk may contain pathogenic bacteria like Salmonella spp., Listeria monocytogenes and Campylobacter jejuni, which can cause illness in humans (Kumbhar et al., 2009; Nanu et al., 2007). Coliforms and enterotoxigenic Escherichia coli have been isolated in raw milk in Zimbabwe and South Africa (Gran et al., 2002; Ibtisam et al., 2008; Mhone et al., 2011). Preparation of mutandabota is carried out at household level in a shaded open space and does not use aseptic techniques. When mutandabota is contaminated by pathogens and then consumed, it might cause microbial infection amongst its consumers.

On the basis of mutandabota, a variant of mutandabota fermented with the probiotic Lactobacillus rhamnosus yoba (referred to as yoba mutandabota) was developed to enable resource-poor populations in Southern Africa to benefit from a functional food (Mpofu et al., 2014b). L. rhamnosus yoba was isolated from a commercially available product, containing L. rhamnosus GG. The identity of the isolate was confirmed by $16 \mathrm{~S}$ rRNA sequencing and the isolate was deposited at the Belgian Co-ordinated Collections of microorganisms/Laboratorium voor Microbiologie Gent (BCCM/LMG) culture collection under the name of L. rhamnosus yoba (Kort and Sybesma, 2012). There is evidence of beneficial effects of $L$. rhamnosus GG based on clinical trials with double-blind and placebo-controlled cross-over designs for prevention and treatment of diarrhea and gastrointestinal and upper respiratory tract infections in children (Grandy et al., 2010; Hojsak et al., 2010; Guandalini et al., 2000). For the production of yoba mutandabota, a new process was designed based on traditional mutandabota preparation procedures. Two major steps were incorporated into the traditional procedure, namely the boiling of raw milk and fermentation with $L$. rhamnosus yoba. Contamination of the product with pathogenic bacteria may occur after the heat treatment; bacterial pathogens have been isolated from pasteurized milk and products from pasteurized milk (Beukes et al., 2001; Gran et al., 2002; Nyatoti et al., 1997). Producing yoba mutandabota through fermentation might enhance its microbiological safety. This study was performed to investigate the survival of bacterial pathogens in traditional and yoba mutandabota.

\section{Materials and methods}

\subsection{Preparation of L. rhamnosus yoba inoculum}

An isolate of the probiotic bacterium $L$. rhamnosus GG, under the name L. rhamnosus yoba (Kort and Sybesma, 2012), was used in this study. The bacterium was obtained from Yoba for Life Foundation (http://www.yoba4life.com), Amsterdam, The Netherlands. It was stored at $-80{ }^{\circ} \mathrm{C}$, before being freeze-dried for long-term storage at $4{ }^{\circ} \mathrm{C}$ in $50 \mathrm{~mL}$ tubes (Greiner Bio-One, BV, Alphen a/d Rijn, The Netherlands). To prepare the inoculum, baobab fruit pulp was added to UHT full-fat cow's milk to a concentration of $4 \%$ (wt/wt). Freeze dried $L$. rhamnosus yoba was dissolved in this medium, to a concentration of $5 \log \mathrm{cfu} / \mathrm{mL}$, in a fermentation vessel that was incubated at $37{ }^{\circ} \mathrm{C}$ for $24 \mathrm{~h}$. This gave a concentration of approximately $9 \log \mathrm{cfu} / \mathrm{mL} L$. rhamnosus yoba. This culture was sequentially diluted in peptone physiological saline (PPS) with the final dilution $10^{-2}$ done in UHT full-fat cow's milk to give approximately $7 \log \mathrm{cfu} / \mathrm{mL}$ L. rhamnosus yoba. This inoculum was then used for producing yoba mutandabota.

\subsection{Preparation of traditional and yoba mutandabota}

Traditional mutandabota (100 g) was prepared based on the local practice in Binga district, Zimbabwe (17 $36^{\prime} \mathrm{S}, 27^{\circ} 32^{\prime} \mathrm{E}$ ) (Mpofu et al., 2014a). This was done by gradually adding, while continuously shaking, $14 \mathrm{~g}$ of baobab fruit pulp and $7 \mathrm{~g}$ of crystalline sucrose to $79 \mathrm{~g}$ of UHT full-fat cow's milk in a $250 \mathrm{~mL}$ sterile bottle. Manual stirring was continued for 7 min or until a homogeneous mixture was achieved. Yoba mutandabota was prepared as illustrated in Fig. 1 (Mpofu et al., 2014b). To prepare $100 \mathrm{~g}$ of yoba mutandabota, L. rhamnosus yoba inoculum (prepared earlier) was added to $78 \mathrm{~g}$ of UHT full-fat cow's milk to a concentration of $5.5 \log \mathrm{cfu} / \mathrm{mL}$. Dry baobab fruit pulp was then added to give a concentration of $4 \%(\mathrm{wt} / \mathrm{wt})$ and vigorously mixed. This mixture was left to ferment for $24 \mathrm{~h}$ at $37^{\circ} \mathrm{C}$ in a stationary incubator. After the fermentation step, an additional $10 \mathrm{~g}$ of baobab fruit pulp and $7 \mathrm{~g}$ crystalline sucrose were added and mixed for 7 min to obtain a homogeneous mixture of yoba mutandabota. This procedure enabled attainment of approximately $9 \log \mathrm{cfu} / \mathrm{mL}$ L. rhamnosus yoba in yoba mutandabota. The product was ready for consumption.

\subsection{Selection of bacterial pathogens}

Five bacterial pathogenic species were selected to evaluate the food safety risk of traditional and yoba mutandabota, namely Campylobacter jejuni, Listeria monocytogenes, Escherichia coli 0157:H7, Bacillus cereus and Salmonella enterica. The pathogen selection was based on expert advice and scientific literature on pathogens identified as causing foodborne microbial illnesses in Southern Africa, particularly Zimbabwe. The selected pathogenic strains were five strains each of Campylobacter jejuni, Listeria monocytogenes, Escherichia coli 0157:H7 and Bacillus cereus. Then three strains of Salmonella Enteritidis, a strain each of Salmonella Paratyphi B and Salmonella Typhimurium. All pathogenic strains except four, were obtained from the Laboratory of Food Microbiology culture collection, Wageningen University, Wageningen, The Netherlands. Four of the E. coli 0157:H7 strains were obtained from The Netherlands National Institute for Public Health and the Environment, Bilthoven, The Netherlands.

\subsection{Preparing cocktails of bacterial pathogens}

All strains were stored in cryovials in a freezer at $-80^{\circ} \mathrm{C}$ and were revived by plating. L. monocytogenes, Salmonella spp., E. coli 0157:H7 and B. cereus strains were plated individually on Brain Heart Infusion (BHI) agar [37 g BHI broth (Oxoid, Basingstoke, UK) and 12 g agar bacteriological (Oxoid), in $1 \mathrm{~L}$ of distilled water]. C. jejuni strains were plated individually on blood agar [ $40 \mathrm{~g}$ blood agar base (Oxoid) and 7\% sterile blood in $1 \mathrm{~L}$ of distilled water]. BHI agar plates with either $E$. coli, L. monocytogenes or Salmonella spp. were incubated aerobically at $37^{\circ} \mathrm{C}$ for $24 \mathrm{~h}$. Plates with $B$. cereus were incubated aerobically at $30^{\circ}$ $\mathrm{C}$ for $24 \mathrm{~h}$. Plates with $C$. jejuni were incubated microaerobically at $41.5^{\circ} \mathrm{C}$ for $48 \mathrm{~h}$. To prepare the inoculum, a colony of each strain was picked from a respective plate and inoculated into BHI broth, with heart infusion (HI) broth (Oxoid) being used for each C. jejuni strain. Incubation was done in stationary incubators for $24 \mathrm{~h}$, reaching a bacterial broth culture concentration of approximately $9 \log \mathrm{cfu} / \mathrm{mL}$. A cocktail of five strains of each species in suspension was produced by mixing equal portions $(2 \mathrm{~mL})$ of each strain in a sterile test tube. The three strains of Salmonella Enteritidis, a strain each of Salmonella Paratyphi B and Salmonella Typhimurium were mixed together in equal portions $(2 \mathrm{~mL})$ of each strain in a sterile test tube. Each pathogenic bacterial cocktail was then ready for inoculation into mutandabota. In total 5 pathogenic bacterial cocktails were produced.

\subsection{Artificial contamination of traditional and yoba mutandabota}

A pathogenic bacterial cocktail in the respective broth was serially diluted in PPS, with the final dilution $10^{-2}$ done in UHT full-fat cow's milk. Of this, $1 \mathrm{~mL}$ was inoculated into $79 \mathrm{~g}$ UHT full-fat cow's milk that was used to prepare traditional mutandabota, and $1 \mathrm{~mL}$ was inoculated into $78 \mathrm{~g}$ UHT full-fat cow's milk that was used to prepare yoba mutandabota. In both traditional and yoba mutandabota, the initial concentration of the pathogenic cocktail suspension was approximately $5.5 \log \mathrm{cfu} / \mathrm{mL}$. For yoba mutandabota, inoculation of the pathogenic cocktail suspension was done simultaneously with L. rhamnosus yoba inoculation (Section 2.1). Independent triplicate experiments were done with each pathogenic bacterial cocktail. Non inoculated samples (negative controls inoculated with $1 \mathrm{~mL}$ full-fat UHT milk) were also 


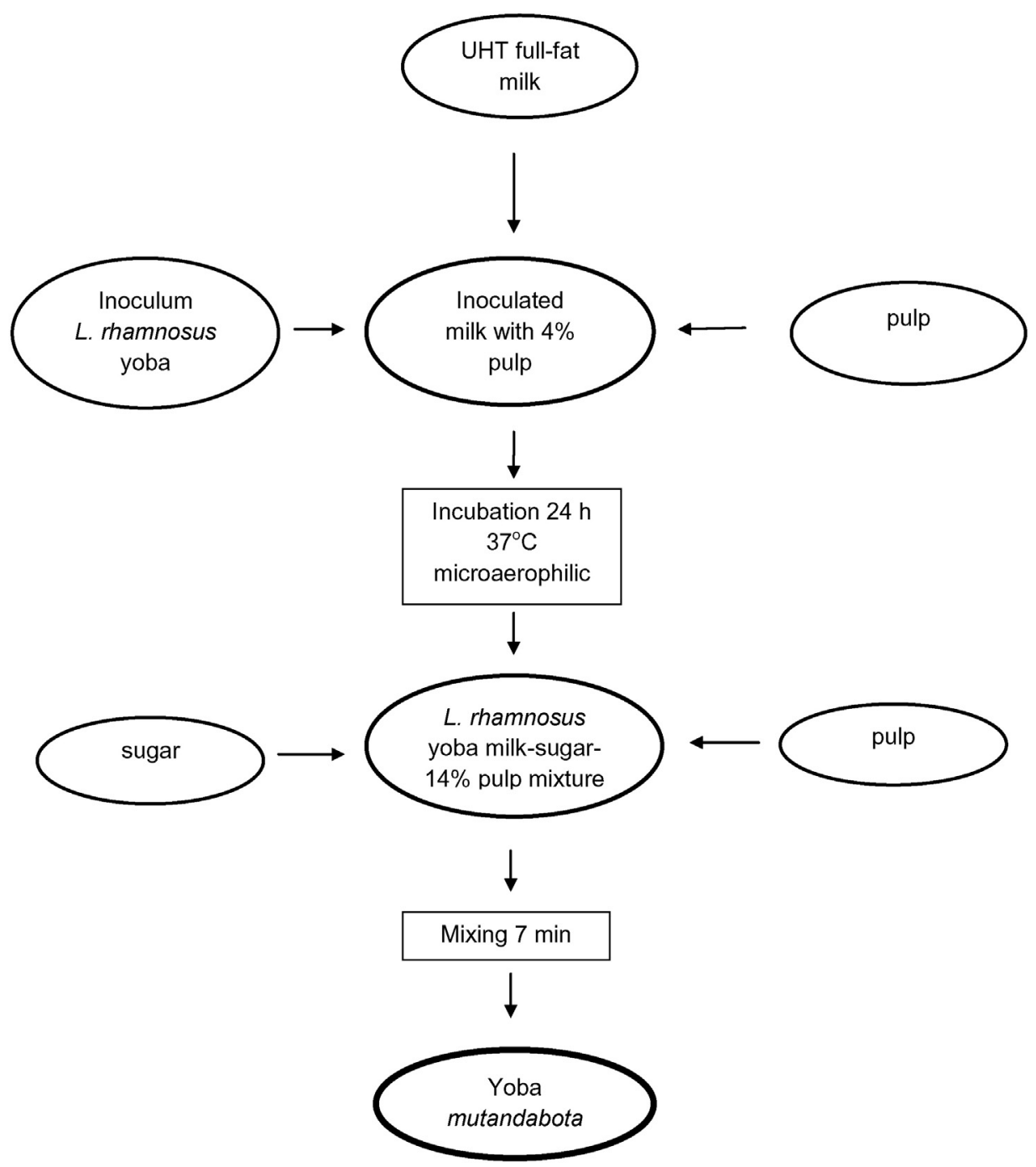

Fig. 1. Flow chart for the production of yoba mutandabota.

tested using the above procedure to confirm that no naturally occurring bacterial pathogens under test, or organisms giving similar colonial morphologies to those added to the inoculated products, were present.

\subsection{Sampling, incubation and enumeration of bacterial strains}

In Southern Africa mutandabota is consumed within $24 \mathrm{~h}$ after preparation. Therefore the survival of pathogens in both traditional and yoba mutandabota was determined over a potential consumption time of $24 \mathrm{~h}$ at $25^{\circ} \mathrm{C}$, to simulate the average ambient temperature in Southern Africa where the product is consumed. For traditional mutandabota, sampling was immediately done after mixing of ingredients and the inoculum (defined as $\mathrm{t}=0$ ), and at approximately $3 \mathrm{~h}$ intervals until the end of the $24 \mathrm{~h}$ storage at $\mathrm{t}=24$. For yoba mutandabota (Fig. 1 ), sampling was immediately after mixing of ingredients and the inoculum (defined as $\mathrm{t}=-24$ ), and at approximately $3 \mathrm{~h}$ intervals throughout the $24 \mathrm{~h}$ fermentation time and the subsequent $24 \mathrm{~h}$ storage time until $t=24$. Sequential serial dilutions were made in PPS and plating was done on selective media followed by incubation under appropriate conditions. For L. monocytogenes, plating was on Agar Listeria Ottavani \& Agosti (bioMerieux, Marcy I'Etoile, France) and incubation was aerobic at $37{ }^{\circ} \mathrm{C}$ for $24 \mathrm{~h}$. For Salmonella spp., plating was on Xylose-LysineDesoxycholate Agar (Oxoid) and incubation was aerobic at $37{ }^{\circ} \mathrm{C}$ for 24 h. For E. coli 0157:H7, plating was on MacConkey agar (Oxoid) and incubation was aerobic at $37^{\circ} \mathrm{C}$ for $24 \mathrm{~h}$. For B. cereus plating was on
Mannitol Egg Yolk Polymyxin Agar (Oxoid) and incubation was aerobic at $30{ }^{\circ} \mathrm{C}$ for $24 \mathrm{~h}$. For C. jejuni plating was on Campy Food Agar (bioMerieux) and incubation was microaerobic at $41.5{ }^{\circ} \mathrm{C}$ for $48 \mathrm{~h}$. For L. rhamnosus yoba, plating was on de Man, Rogosa and Sharpe Agar [MRSA: 12 g agar bacteriological (Oxoid), added to $52.2 \mathrm{~g}$ de Man, Rogosa and Sharpe broth (Merck, Darmstadt, Germany) in $1 \mathrm{~L}$ distilled water] and incubation was under microaerobic conditions at $37^{\circ} \mathrm{C}$ for $24 \mathrm{~h}$. Colonies were enumerated and results were expressed in log $\mathrm{cfu} / \mathrm{mL}$ of either traditional or yoba mutandabota. The detection limit of the plating method was $100 \mathrm{cfu} / \mathrm{mL}$.

\subsection{Lactic acid determination}

Lactic acid was determined by HPLC. Briefly, samples of traditional and yoba mutandabota were deproteinated by adding $0.25 \mathrm{~mL}$ cold Carrez A solution (42.2 $\mathrm{g} \mathrm{K}_{4} \mathrm{Fe}(\mathrm{CN})_{6} \cdot 3 \mathrm{H}_{2} \mathrm{O}$ per $1 \mathrm{~L}$ demineralized water) (Sigma-Aldrich, Steinheim, Germany) to $0.5 \mathrm{~mL}$ sample of traditional or yoba mutandabota in an Eppendorf tube and mixed, then $0.25 \mathrm{~mL}$ of cold Carrez B solution $\left(57.5 \mathrm{~g} \mathrm{ZnSO}{ }_{4} \cdot 7 \mathrm{H}_{2} \mathrm{O}\right.$ per $1 \mathrm{~L}$ demineralized water) (Sigma-Aldrich, Steinheim, Germany) was added and mixed. The Eppendorf tubes with samples were centrifuged and the supernatant was taken for HPLC analysis (Ultimate 3000, Dionex), using an Aminex HPX-87 H $300 \times 7.8 \mathrm{~mm}$ column with a pre-column (Biorad). The eluent was $5 \mathrm{mM} \mathrm{H}_{2} \mathrm{SO}_{4}$ at a flow rate of 0.6 
$\mathrm{ml} / \mathrm{min}$ at $40{ }^{\circ} \mathrm{C}$. Detection was done by refractive index (Shodex RI 101). Sample volume was $10 \mu \mathrm{L}$ and the run time was $30 \mathrm{~min}$.

\section{8. $\mathrm{pH}$ measurement}

The $\mathrm{pH}$ values during the experiments were measured using a combined glass electrode pH meter (WTW, Weilheim, Germany) that was calibrated using standard buffer solutions (Merck, Darmstadt, Germany) at $\mathrm{pH} 4.0$ and 7.0. The $\mathrm{pH}$ was determined each time a sample was taken for microbial analysis at times indicated above.

\subsection{Statistical analysis}

Independent experiments including inoculum preparation, product making and storage were performed in triplicate. Data points were represented by the mean, with the standard deviation indicated by error bars. The mean values of $\mathrm{pH}$ of all samples as well as mean log counts of the bacterial pathogens and L. rhamnosus yoba were compared using one-way ANOVA and Tukey's post-hoc tests. Statistical analysis was done using SPSS 13.0 for Windows (Apache Software Foundation, Forest Hill, Maryland, USA) and Microsoft Excel.

\section{Results and discussion}

\section{1. $p H$ changes in traditional and yoba mutandabota}

The time course of acidification in traditional mutandabota was similar in all experiments with the 5 cocktails of bacterial pathogens (Figs. 2 to 6$)$. The pH was $3.5(n=15)$ immediately after preparation when mutandabota was ready for consumption at time $0 \mathrm{~h}(\mathrm{t}=0)$. This $\mathrm{pH}-$ value remained rather constant throughout the $24 \mathrm{~h}$ potential consumption time, also regarded as the storage period, and at $\mathrm{t}=24$ the $\mathrm{pH}$ was $3.4 \pm 0.1$. The low $\mathrm{pH}$ could be attributed to the acidic nature of dry baobab fruit pulp. Airan and Desai (1954) and Carr (1955) first highlighted the presence of organic acids in baobab fruit pulp. Later reports by Nour et al. (1980) and Vertuani et al. (2002) confirmed the presence of citric, tartaric, malic, succinic and ascorbic acids in baobab fruit pulp. For yoba mutandabota (Figs. 2 to 6 ) at the moment of simultaneous inoculation with L. rhamnosus yoba and the pathogenic bacteria cocktail into the $4 \%$ pulp-milk mixture $(t=-24 \mathrm{~h})$, the $\mathrm{pH}$ was $4.2 \pm$ $0.1(n=15)$. After $9 \mathrm{~h}$ the $\mathrm{pH}$ remained stable at 4.2 . At $\mathrm{t}=0$, signaling the end of the fermentation stage, the $\mathrm{pH}$ was $3.7 \pm 0.1$. The lowering of $\mathrm{pH}$ from 4.2 to 3.7 during the fermentation phase could be attributed to organic acids such as lactic acid produced by the fermenting $L$. rhamnosus yoba. When the remaining $10 \%$ pulp and $7 \%$ sugar were added to get the standard constituents of mutandabota, the $\mathrm{pH}$ remained stable at $3.7 \pm 0.1$. Yoba mutandabota was then ready for

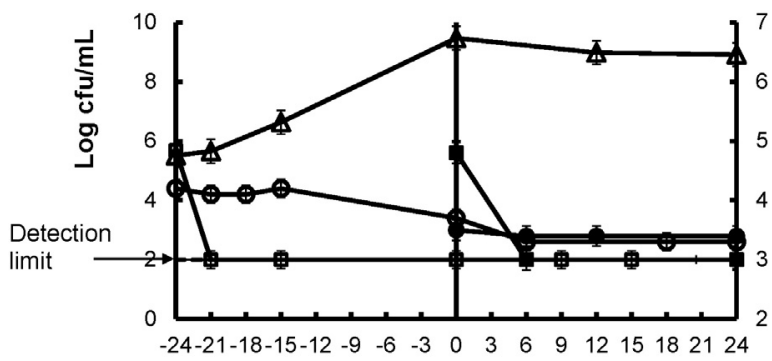

$\mathrm{pH}$

Fermentation time (h) Potential consumption time (h)

Fig. 2. Kinetics of Lactobacillus rhamnosus yoba and Bacillus cereus during production of traditional and yoba mutandabota. Fermentation takes $24 \mathrm{~h}, 0 \mathrm{~h}$ is the start of potential consumption time; (open triangle) Lactobacillus rhamnosus yoba in yoba mutandabota, (closed square) B. cereus in traditional mutandabota, (open square) B. cereus in yoba mutandabota, (closed circle) pH changes in traditional mutandabota, (open circle) pH changes in yoba mutandabota. Points represented on the detection limit indicate results below the detection limit (no detection).

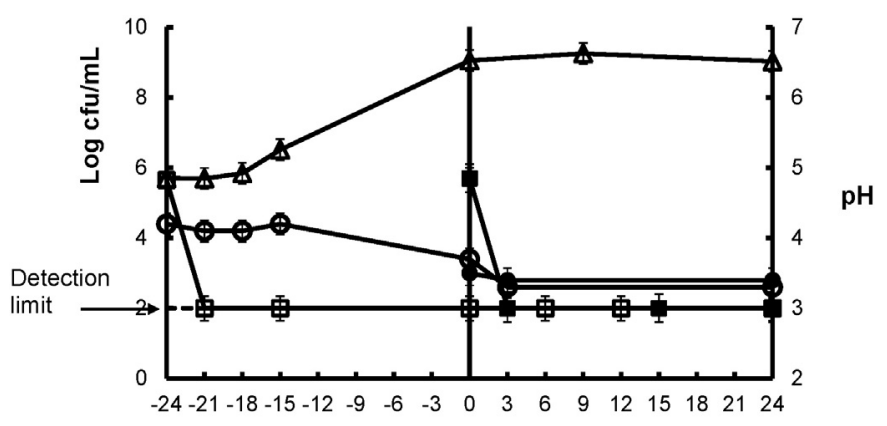

fermentation time (h) Potential consumption time (h)

Fig. 3. Kinetics of Lactobacillus rhamnosus yoba and Campylobacter jejuni during production of traditional and yoba mutandabota. Fermentation takes $24 \mathrm{~h}, 0 \mathrm{~h}$ is the start of potential consumption time; (open triangle) Lactobacillus rhamnosus yoba in yoba mutandabota, (closed square) $C$. jejuni in traditional mutandabota, (open square) C. jejuni in yoba mutandabota, (closed circle) pH changes in traditional mutandabota, (open circle) pH changes in yoba mutandabota.

consumption. The $\mathrm{pH}$ remained rather constant at $3.3 \pm 0.1$ throughout the storage period of yoba mutandabota resulting in a $\mathrm{pH}$ of $3.3 \pm 0.1$ at $\mathrm{t}=24$.

In preliminary experiments to determine growth of $L$. rhamnosus yoba at different $\mathrm{pH}$ values obtained by mixing different concentrations of baobab fruit pulp and UHT full fat cow's milk, it was shown that a fruit pulp content of $2 \%$ gave a $\mathrm{pH}$ of 5 . This $\mathrm{pH}$ value allowed growth of $L$. rhamnosus yoba but was not enough to sustain growth of the bacterium over a $24 \mathrm{~h}$ period due to substrate limitation. Doubling the amount of fruit pulp to $4 \%$ resulted in a $\mathrm{pH}$ of 4.2 . This pulp concentration of $4 \%$ and $\mathrm{pH}$ value of 4.2 allowed sustained growth of $L$. rhamnosus yoba over a $24 \mathrm{~h}$ period. Further doubling of the fruit pulp concentration to $8 \%$ resulted in a further decrease in $\mathrm{pH}$ (3.9), which allowed survival of $L$. rhamnosus yoba, but not its growth (Mpofu et al., 2014b).

\subsection{Growth of L. rhamnosus yoba in yoba mutandabota with pathogens}

L. rhamnosus yoba, an isolate of the probiotic bacterium $L$. rhamnosus GG (Kort and Sybesma, 2012) was chosen for this study. L. rhamnosus GG, originally cultured from a healthy human intestinal source, has been thoroughly studied and used safely as a probiotic strain in a variety of probiotic foods (Bernardeau et al., 2006; Hatakka et al., 2001; Kalliomäki et al., 2001). L. rhamnosus GG is widely prescribed for treatment of acute diarrhea in children, its efficacy was evaluated by in vivo studies (Canani et al., 2007; Grandy et al., 2010; Hojsak et al., 2010). The growth of $L$. rhamnosus yoba in yoba mutandabota followed a similar pattern in each experiment (Figs. 2 to 6). Generally, from an inoculation

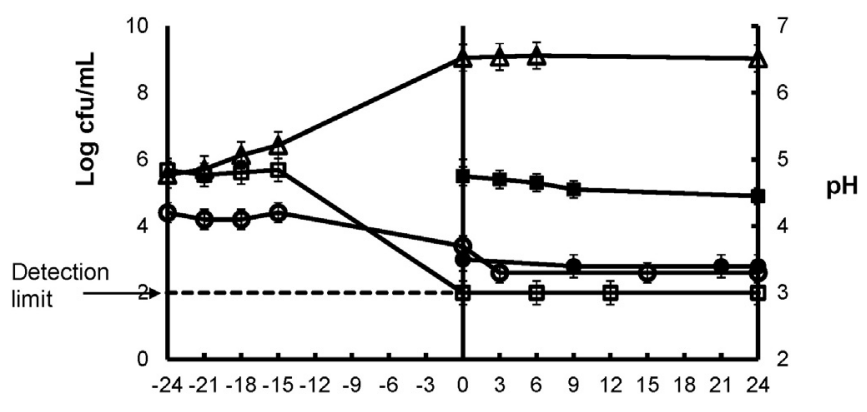

Fermentation time (h)

Potential consumption time (h)

Fig. 4. Kinetics of Lactobacillus rhamnosus yoba and Listeria monocytogenes during production of traditional and yoba mutandabota. Fermentation takes $24 \mathrm{~h}, 0 \mathrm{~h}$ is the start of potential consumption time; (open triangle) Lactobacillus rhamnosus yoba in yoba mutandabota, (closed square) Listeria monocytogenes in traditional mutandabota, (open square) Listeria monocytogenes in yoba mutandabota, (closed circle) $\mathrm{pH}$ changes in traditional mutandabota, (open circle) pH changes in yoba mutandabota. 


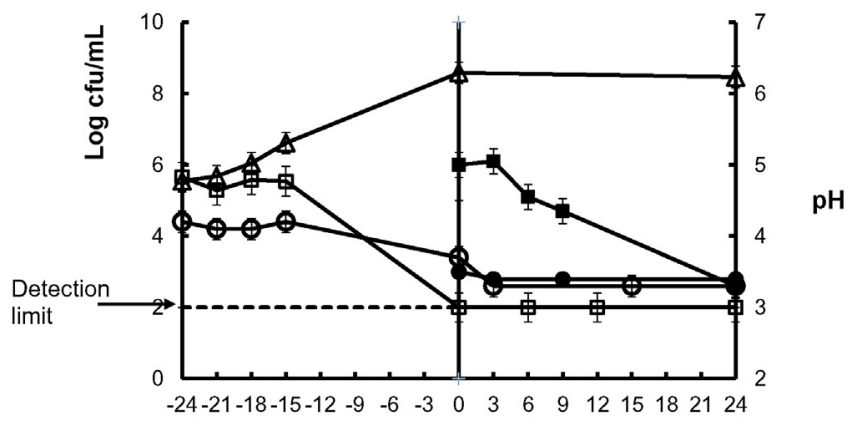

fermentation time (h) Potential consumption time (h)

Fig. 5. Kinetics of Lactobacillus rhamnosus yoba and Escherichia coli 0157:H7 during production of traditional and yoba mutandabota. Fermentation takes $24 \mathrm{~h}, 0 \mathrm{~h}$ is the moment of start of potential consumption time; (open triangle) Lactobacillus rhamnosus yoba in yoba mutandabota, (closed square) E. coli 0157:H7 in traditional mutandabota, (open square) E. coli 0157:H7 in yoba mutandabota, (closed circle) pH changes in traditional mutandabota, (open circle) pH changes in yoba mutandabota.

level of $5.5 \pm 0.1 \log \mathrm{cfu} / \mathrm{mL}$, L. rhamnosus yoba showed robustness and increased counts in the presence of pathogens, in some instance, even with increasing pathogen concentration, such as Salmonella (Fig. 6). $L$. rhamnosus yoba reached $6.6 \pm 0.2 \log \mathrm{cfu} / \mathrm{mL}$ at $\mathrm{t}=-15$, and further increased to $9.1 \pm 0.4 \log \mathrm{cfu} / \mathrm{mL}$ at $\mathrm{t}=0$, which was the end of the fermentation process. At this time the remaining baobab fruit pulp and sugar were added to reach the standard $14 \%$ pulp and $7 \%$ sugar in yoba mutandabota. At the end of the storage time, $\mathrm{t}=24$, L. rhamnosus yoba viable counts were at $8.5 \pm 0.9 \log \mathrm{cfu} / \mathrm{mL}$.

\subsection{Survival and decline of pathogens in traditional and yoba mutandabota}

The loss in viability of B. cereus and C. jejuni inoculated into traditional mutandabota and yoba mutandabota is depicted in Figs. 2 and 3 respectively. The harsh effect of the acidic environment with a $\mathrm{pH}$ of 3.5 was pronounced. From an inoculation level of 5.6 and $5.7 \log \mathrm{cfu} / \mathrm{mL} B$. cereus and $C$. jejuni respectively, in both traditional and yoba mutandabota, both pathogens could not be detected $3 \mathrm{~h}$ after inoculation. $B$. cereus does not have a marked tolerance for environments with $\mathrm{pH}$ values below 4.5. Hassan et al. (2010) noted that vegetative cells of $B$. cereus rapidly die in yoghurt, a comparable product to yoba mutandabota, hence acidification is a common method of preservation. Working on yoghurt, Ayoub et al. (2003) found that 20\% of examined yoghurt samples were tested positive for $B$. cereus. Lower incidence of B. cereus was reported by Hassan et al. (2010), who found 2\% (1 out of 50) of yoghurt samples positive for B. cereus. Conversely, Khalil (1997) and Abdel-Khalek (2002) did not detect B. cereus in yoghurt. The

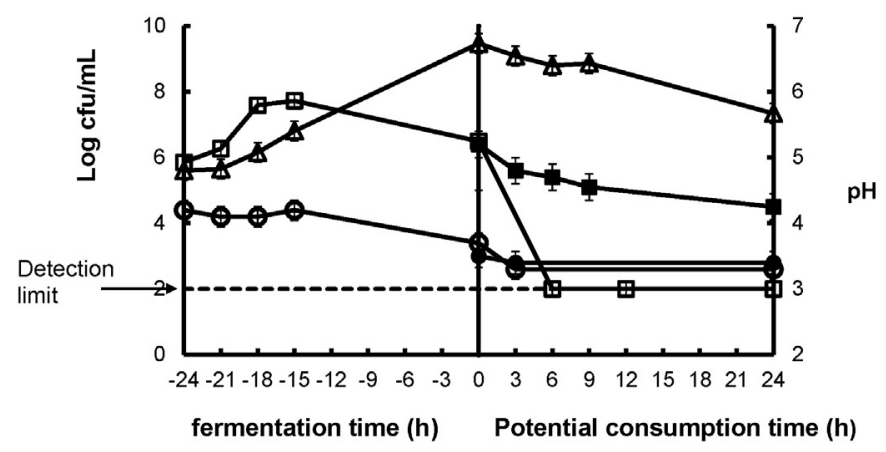

Fig. 6. Kinetics of Lactobacillus rhamnosus yoba and Salmonella spp. during production of traditional and yoba mutandabota. Fermentation takes $24 \mathrm{~h}, 0 \mathrm{~h}$ is the moment of start of potential consumption time; (open triangle) Lactobacillus rhamnosus yoba in yoba mutandabota, (closed square) Salmonella spp. in traditional mutandabota, (open square) Salmonella spp. in yoba mutandabota,(closed circle) pH changes in traditional mutandabota over a period of $24 \mathrm{~h}$, (open circle) $\mathrm{pH}$ changes in yoba mutandabota. lower incidence or absence of $B$. cereus in yoghurt was attributed to the inhibitory effect of lactic acid bacteria on B. cereus. Simango and Rukure (1991) observed a similar trend for C. jejuni inactivation in mahewu, a traditional fermented cereal beverage in Zimbabwe. They showed that none of the 4 strains of $C$. jejuni tested survived for $30 \mathrm{~min}$ in mahewu ( $\mathrm{pH}$ 3.6) although high inocula of 6 to $7 \log \mathrm{cfu} / \mathrm{mL}$ were used. C. jejuni was also shown to die rapidly within $30 \mathrm{~min}$ in yoghurt (Cuz et al., 1987) and within $2 \mathrm{~h}$ at pH 4 in the presence of formic acid (Chaveerach et al., 2003). Rahimi et al. (2013), investigating the prevalence of Campylobacter spp. in milk and dairy products, isolated C. jejuni from raw cow's milk, goat's milk and traditional cheese made from raw milk. No C. jejuni was isolated from pasteurized milk, yoghurt and commercial dairy products. Boiling milk or pasteurization is believed to be sufficient to inactivate C. jejuni (D'Aoust et al., 1988). The combination of organic acids and low pH of both types of mutandabota could explain the failure of B. cereus and C. jejuni to survive in the products during production and the period of potential consumption. In conclusion, when stored, both traditional and yoba mutandabota are unlikely to be sources of $B$. cereus and $C$. jejuni infection.

In traditional mutandabota (Figs. 4 and 5), L. monocytogenes and $E$. coli 0157:H7 from inoculation levels of 5.5 and $5.9 \log \mathrm{cfu} / \mathrm{mL}$, decreased to 5.1 and $4.7 \log \mathrm{cfu} / \mathrm{mL}$ respectively after $9 \mathrm{~h}$. At the end of the period of potential consumption at $t=24$, they were 4.9 and $2.6 \log \mathrm{cfu} / \mathrm{mL}$ respectively, a significant $(\mathrm{P}<0.05)$, but limited decline. Although contamination is unlikely to reach the levels used in this study, it is evident that low $\mathrm{pH}$ alone $(3.5 \pm 0.1)$ will not completely inactivate the two bacterial pathogens and will not guarantee microbiological safety of traditional mutandabota. It must be accompanied by other measures, such as controlled fermentation, to produce a fermented product with antimicrobial properties. In yoba mutandabota (Figs. 4 and 5), L. monocytogenes and E. coli 0157:H7 remained rather constant at the inoculated level of 5.7 and $5.9 \log \mathrm{cfu} / \mathrm{mL}$ respectively, for the first 9 h. However, no L. monocytogenes or E. coli 0157:H7 could be detected at $t=0$, the end of fermentation. The decrease of $L$. monocytogenes and $E$. coli $0157: \mathrm{H} 7$ corresponded to an increase in $L$. rhamnosus yoba from $5.5 \log \mathrm{cfu} / \mathrm{mL}$ at $\mathrm{t}=-24$ to $9.1 \log \mathrm{cfu} / \mathrm{mL}$ at $\mathrm{t}=0$ at the end of the fermentation (Figs. 4 and 5). When the remaining pulp and sugar were added to prepare mutandabota for consumption, yoba mutandabota was microbiologically safe to consume.

Similar observations were made by Dalu and Feresu (1995), working on traditionally fermented unpasteurized and pasteurized milk and on an industrially fermented milk marketed in Zimbabwe. Their results indicated that $L$. monocytogenes was inactivated at different levels during fermentation and storage of all the three fermented milk products ( $\mathrm{pH} 4.5$ and stored at $20^{\circ} \mathrm{C}$ ). In a study to investigate the survival of bacterial pathogens that had been associated with childhood diarrhea in Zimbabwe, Simango and Rukure (1991), showed that starting with a high inoculum of 6 to $7 \log \mathrm{cfu} / \mathrm{mL}$ in mahewu, all strains of enteropathogenic and enterotoxigenic E. coli were detected in mahewu (pH 3.6) after $24 \mathrm{~h}$ of storage at $25^{\circ} \mathrm{C}$. Most of the $E$. coli strains showed very little change in numbers of surviving cells. The current study demonstrated that inactivation of L. monocytogenes and E. coli 0157:H7 in yoba mutandabota was probably due to a combined effect of a low pH of 3.4 , organic acids and possibly other fermentation products produced by the fermenting $L$. rhamnosus yoba, since in traditional mutandabota ( $\mathrm{pH}$ 3.5), the two pathogens survived rather well.

In traditional mutandabota, there was a decrease of Salmonella spp. throughout the potential consumption period of $24 \mathrm{~h}$ (Fig. 6). From an inoculation level of $6.4 \log \mathrm{cfu} / \mathrm{mL}$, the Salmonella counts decreased to $5.1 \log \mathrm{cfu} / \mathrm{mL}$ at $\mathrm{t}=9$, and $4.5 \log \mathrm{cfu} / \mathrm{mL}$ at the end of the potential consumption time, $t=24$, a significant decrease $(P<0.05)$ by $2 \log$ units. However, the level still remained above the detection limit. This reflects that once contaminated with Salmonella spp., traditional mutandabota could be a health hazard. Meanwhile in yoba mutandabota, Salmonella spp. increased from an inoculation level of $5.8 \mathrm{log} \mathrm{cfu} / \mathrm{mL}$ at $\mathrm{t}=-24$ to $7.7 \log \mathrm{cfu} / \mathrm{mL}$ at $\mathrm{t}=-15$, giving higher levels than $L$. 
rhamnosus yoba during the first $9 \mathrm{~h}$ of fermentation (Fig. 6). This suggests that with a $\mathrm{pH}$ of 4.2 , the milk-pulp mixture provided a conducive environment for proliferation of Salmonella. The Salmonella spp. then decreased to $6.5 \log \mathrm{cfu} / \mathrm{mL}$ at the end of fermentation at $\mathrm{t}=0$. The remaining $10 \%$ pulp and sugar were then added, subsequently within $6 \mathrm{~h}$, no Salmonella could be detected (Fig. 6). This suggests that Salmonella spp. could not withstand the additional hurdle due to the added pulp. It should be noted that the other tested pathogens in this study did not need this extra hurdle to be inactivated below the detection threshold. Mufandaedza et al. (2006) observed a similar trend with $S$. Enteritidis in naturally fermented milk and industrially fermented milk ( $\mathrm{pH}$ 4.4). S. Enteritidis grew from $7 \mathrm{log} \mathrm{cfu} / \mathrm{mL}$ to reach high populations of about 9 and $8.8 \log \mathrm{cfu} / \mathrm{mL}$ respectively, after $18 \mathrm{~h}$. But $S$. Enteritidis could not be recovered from the cultures after $48 \mathrm{~h}$. The inhibitory effect was associated with fast acid production by the fermenting lactic acid bacteria, which resulted in a pH reduction. Several investigations have demonstrated that Salmonella spp. can survive in acidic foods at lower $\mathrm{pH}$ values for longer periods of time. Indeed, declining numbers of viable cells have been detected up to 12 weeks in apple, orange, pineapple and white grape juice concentrates (Oyarzabal et al., 2003; Parish et al., 1997) and 10 weeks in yoghurt (El-Gazzar and Marth, 1992). Mugochi et al. (1999) found that within $30 \mathrm{~min}$ of inoculation at 6 to $7 \mathrm{log} \mathrm{cfu} / \mathrm{mL}$, there were no viable Salmonella group B and Salmonella Enteritidis in the fermented mapfura (Sclerocarya birrea subsp. caffra) juice ( $\mathrm{pH} 3.4$ ), while in the unfermented juice, more than $4 \log \mathrm{cfu} / \mathrm{mL}$ were still viable after $8 \mathrm{~h}$ ( $\mathrm{pH} 3.4$ ). However, none were still present after $24 \mathrm{~h}$. They attributed the disappearance of Salmonella to antimicrobial substances in the fermented mapfura juice.

Control of pathogens in mutandabota and other dairy products is important because these pathogens or their toxins, endanger public health upon consumption of contaminated foods. C. jejuni is one of the most important causes of diarrhea in infants under 2 years of age in Southern Africa (Simango and Rukure, 1991; Kotloff et al., 2013). The disease caused by $C$. jejuni usually manifests itself as diarrhea, fever, malaise and severe abdominal pain. More recent studies suggest that $C$. jejuni infections can lead to inflammatory bowel diseases such as Crohn's disease (Horrocks et al., 2009). The ability of L. monocytogenes to survive in traditional mutandabota is of public health significance. $L$. monocytogenes can cause meningitis, encephalitis, abortion, premature birth, stillbirth, and gastroenteritis (Seeliger and Jones, 1986; Siegman-Igra et al., 2002). The poor inactivation of $E$. coli in traditional mutandabota coupled with the low infective dose of verotoxin-producing $E$. coli (VTEC), the increase in incidence of infection by $E$. coli 0157:H7 and emergence of other VTEC sero-groups such as 0111 and O26 (Baylis et al., 2004), does give cause for concern, especially for susceptible consumer groups, such as children and elderly. In the control challenge experiments no growth of pathogens was observed, this confirmed that no naturally occurring bacterial pathogens under test, or organisms giving similar colonial morphologies to those added to the inoculated products, were present.

The inactivation of pathogens in yoba mutandabota was clearly enhanced by fermenting with $L$. rhamnosus yoba. The bacterial pathogens could not survive in yoba mutandabota during the potential consumption time. This was probably due to lactic acid and other organic acids produced by $L$. rhamnosus yoba during the fermentation process. Yoba mutandabota is thus safer than traditional mutandabota during the potential consumption time. In producing yoba mutandabota, the inoculum was diluted approximately $1: 80$, this greatly reduces the chances, but does not exclude the inhibition being caused by a compound present in the pre-inoculum, further work on this aspect would be of value. No lactic acid was detected in traditional mutandabota, however in yoba mutandabota the amount of lactic acid was $2.2 \pm 1.2 \mathrm{~g} / \mathrm{L}$. This is on the lower side when compared with studies done by Østlie et al. (2003), in which lactic acid produced by L. rhamnosus GG (ATCC 53103 ) was $7 \mathrm{~g} / \mathrm{L}$ after $24 \mathrm{~h}$ of fermentation in UHT milk supplemented with $0.75 \%(w / v)$ fructose. So far, in literature the role of lactic acid in the antimicrobial activity of L. rhamnosus GG is controversial with hypotheses being formulated that range from minimal or no role at all (Silva et al., 1987; Fayol-Messaoudi et al., 2005) to lactic acid being the major antimicrobial agent (Makras et al., 2006; Marianelli et al., 2010; Hutt et al., 2006). While some Lactobacillus strains such as L. acidophilus and L. casei produce bacteriocins, there is still controversy on production of bacteriocins by L. rhamnosus GG (Avonts et al., 2004; Lu et al., 2009). Bacteriocins have specific inhibitory activity against Gram positive bacteria (Abee et al., 1995), whereas organic acids are known to have specific inhibitory activity against both Gram negative and Gram positive pathogens (Alakomi et al., 2000; De Keersmaecker et al., 2006; Fayol-Messaoudi et al., 2005). Lu et al. (2009) isolated and characterized 7 peptides produced by L. rhamnosus GG, the peptide NPSRQERR showed the highest antibacterial properties, both on Gram negative and Gram positive bacteria. Kankainen et al. (2009) described the presence of several bacteriocin related genes in the genome of L. rhamnosus GG. It is of value to investigate further the antimicrobial action of $L$. rhamnosus yoba in yoba mutandabota.

\section{Conclusion}

This study focused on the question whether five important pathogens, namely, L. monocytogenes, Salmonella spp., C. jejuni, E. coli 0157:H7 and B. cereus, could pose a foodborne risk to consumers of both traditional and yoba mutandabota. In traditional mutandabota ( $\mathrm{pH}$ 3.5) no viable B. cereus and C. jejuni were detected $3 \mathrm{~h}$ after inoculation. However, L. monocytogenes, Salmonella spp., and E. coli 0157:H7 significantly declined $(\mathrm{P}<0.05)$, but could still be detected at the end of the storage period. This indicates that consumption of traditional mutandabota exposes consumers to the risk of food-borne microbial infections. In yoba mutandabota, the $\mathrm{pH}$ dropped from $4.2 \pm 0.1$ to $3.7 \pm$ 0.1 after $24 \mathrm{~h}$ of fermentation, and remained rather constant at $\mathrm{pH}$ $3.7 \pm 0.1$ throughout the $24 \mathrm{~h}$ storage period. L. rhamnosus yoba showed robustness in yoba mutandabota and grew from $5.5 \pm 0.1$ to $9.1 \pm$ $0.4 \log \mathrm{cfu} / \mathrm{mL}$, even in the presence of pathogens during fermentation. None of the bacterial pathogens tested survived during production and/ or storage of yoba mutandabota. Yoba mutandabota was made from pasteurized milk, and in practice, this will also largely reduce the risk of contaminated milk with pathogens. Our findings demonstrate that yoba mutandabota fermented with $L$. rhamnosus yoba has antimicrobial properties against the tested bacterial pathogens and can thus be regarded as a safer product compared to its traditional counterpart. Inactivation of pathogens in mutandabota is of public health significance because food-borne pathogens endanger public health upon consumption of contaminated mutandabota. Improving safety of mutandabota should also be achieved by providing information to food handlers and consumers on food hygiene to reduce the risk of contamination of mutandabota.

\section{Acknowledgments}

The authors thank NUFFIC (Grant award number CF6631/2010) for financial assistance, Yoba for Life Foundation for supplying the Lactobacillus rhamnosus yoba strain, and Dr. Eelco Franz for the supply of Escherichia coli 0157:H7 strains from Netherlands National Institute for Public Health and the Environment.

\section{References}

Abdel-Khalek, A., 2002. Incidence and characterization of enterotoxigenic Bacillus cereus in some dairy products. Suez Canal Vet. Med. J. 1, 1-10.

Abee, T., Krockel, L., Hill, C., 1995. Bacteriocins: modes of action and potentials in food preservation and control of food poisoning. Int. J. Food Microbiol. 28, 169-185.

Airan, I.W., Desai, R.M., 1954. Sugars and organic acids in Adansonia digitata L. J. Univ. Bombay 22, 23-27. 
Alakomi, H.L., Skytta, E., Saarela, M., Mattila-Sandholm, T., Latva-Kala, K., Helander, I.M., 2000. Lactic acid permeabilises Gram negative bacteria by disrupting the outer membrane. Appl. Environ. Microbiol. 66, 2001-2005.

Avonts, L., Uytven, E., Vuyst, L., 2004. Cell growth and bacteriocin production of probiotic Lactobacillus strains in different media. Int. Dairy J. 14, 947-955.

Ayoub, M.A., El-Shayeb, T.M., Zaki, M.S.A., 2003. Characterization of Bacillus cereus isolated from raw milk and some dairy products. Suez Canal Vet. Med. J. 5, 123-133.

Baylis, C.L., MacPhee, S., Robinson, A.J., Griffiths, R., Lilley, K., Betts, R.P., 2004. Survival of Escherichia coli 0157:H7, 0111:H and 026:H11 in artificially contaminated chocolate and confectionery products. Int. J. Food Microbiol. 96, 35-48.

Bernardeau, M., Guguen, M., Vernoux, J.P., 2006. Beneficial lactobacilli in food and feed: long-term use, biodiversity and proposals for specific and realistic safety assessments. FEMS Microbiol. Rev. 30, 487-513.

Beukes, E.M., Bester, B.H., Mostert, J.F., 2001. The microbiology of South African traditional fermented milks. Int. J. Food Microbiol. 63, 189-197.

Canani, R.B., Cirillo, P., Terrin, G., Cesarano, L., Spagnuolo, M.I., De Vincenzo, A., Albano, F., Passariello, A., De Marco, G., Manguso, F., Guarino, A., 2007. Probiotics for treatment of acute diarrhea in children: randomised clinical trial of five different preparations. Br. Med. J. 335, 340-349.

Carr, W.R., 1955. Ascorbic acid content of baobab fruit. Nature 4496, 1273-1274.

Chaveerach, P., ter Huurne, A.A.H.M., Lipman, L.J.A., van Knapen, F., 2003. Survival and resuscitation of ten strains of Campylobacter jejuni and Campylobacter coli under acid conditions. Appl. Environ. Microbiol. 69, 711-714.

Cuz, Z., Annan-Prah, A., Janc, M., Zajc-Satler, J., 1987. Yoghurt, an unlikely source of Campylobacter jejuni/coli. J. Appl. Bacteriol. 63, 201-205.

Dalu, J.M., Feresu, S.B., 1995. Survival of Listeria monocytogenes in three Zimbabwean fermented milk products. J. Food Prot. 59, 379-383.

D'Aoust, J.Y., Park, C.E., Szabo, R.A., Todd, E.C.D., Emmons, D.B., McKellar, R.C., 1988. Thermal inactivation of Campylobacter species, Yersinia enterocolitica, and hemorrhagic Escherichia coli 0157:H7 in fluid milk. J. Dairy Sci. 71 (12), 3230-3236.

De Keersmaecker, S.C., Verhoeven, T.L., Desair, J., Marchal, K., Vanderleyden, J., Nagy, I., 2006. Strong antimicrobial activity of Lactobacillus rhamnosus GG against Salmonella Typhimurium is due to accumulation of lactic acid. FEMS Microbiol. Lett. 259, 89-96.

El-Gazzar, F.E., Marth, E.H., 1992. Salmonellae, salmonellosis and dairy foods: a review. J. Dairy Sci. 75, 2327-2343.

Fayol-Messaoudi, D., Berger, C.N., Coconnier-Polter, M.H., Lie'vin-Le Moal, V., Servin, A.L., 2005. pH-, lactic acid-, and non-lactic acid dependent activities of probiotic lactobacilli against Salmonella enterica Serovar Typhimurium. Appl. Environ. Microbiol. 71, 6008-6013.

Gran, H.M., Wetlesen, A., Mutukumira, A.N., Narvhus, J.A., 2002. Smallholder dairy processing in Zimbabwe: hygienic practices during milking and the microbiological quality of the milk at the farm and on delivery. Food Control 13, 41-47.

Grandy, G., Medina, M., Soria, R., Terán, C.G., Araya, M., 2010. Probiotics in the treatment of acute rotavirus diarrhoea. A randomized, double-blind, controlled trial using two different probiotic preparations in bolivian children. BMC Infect. Dis. 10, 253-266.

Guandalini, S., Pensabene, L., Zikri, M.A., Dias, J.A., Casali, L.G., Hoekstra, H., Kolacek, S., Massar, K., Micetic-Turk, D., Papadopoulou, A., de Sousa, J.S., Sandhu, B., Szajewska, H., Weizman, Z., 2000. Lactobacillus GG administered in oral rehydration solution to children with acute diarrhea: a multicenter European trial. J. Pediatr. Gastroenterol. Nutr. 30, 54-60.

Hassan, G.M., Al-Ashmawy, M.A.M., Meshref, A.M.S., Afify, S.I., 2010. Studies on enterotoxigenic Bacillus cereus in raw milk and some dairy products. J. Food Saf. 30, 569-583.

Hatakka, K., Savilahti, E., Pönkä, A., Meurman, J.H., Poussa, T., Näse, L., Saxelin, M., Korpela, R., 2001. Effect of long term consumption of probiotic milk on infections in children attending day care centres: double blind, randomised trial. Br. Med. J. 322, 1327-1329.

Hojsak, I., Snovak, N., Abdovic, S., Szajewska, H., Misak, Z., Kolacek, S., 2010. Lactobacillus rhamnosus GG in the prevention of gastrointestinal and respiratory tract infections in children who attend day care centers: a randomized, double-blind, placebo-controlled trial. Clin. Nutr. 29, 312-316.

Horrocks, S.M., Anderson, R.C., Nisbet, D.J., Ricke, S.C., 2009. Incidence and ecology of Campylobacter jejuni and coli in animals. Food Microbiol. 15, 18-25.

Hutt, P., Shchepetova, J., Loivukene, K., Kullisaar, T., Mikelsaar, M., 2006. Antagonistic activity of probiotic lactobacilli and bifidobacteria against entero- and uropathogens. J. Appl. Microbiol. 100, 1324-1332.

Ibtisam, E.M., Zubeir, E.1., Gabriechise, V., Johnson, Q., 2008. Comparison of chemical composition and microbial profile of raw and pasteurised milk of the Western Cape, South Africa. Int. J. Dairy Sci. 3, 137-143.

ICMSF, 2002. International Commission on Microbiological Specifications for Foods. Microbiological Testing in Food Safety Management. Springer Science, New York, USA.

Kalliomäki, M., Salminen, S., Arvilommi, H., Kero, P., Koskinen, P., Isolauri, E., 2001. Probiotics in primary prevention of atopic disease: a randomised placebo-controlled trial. Lancet 357, 1076-1079.

Kankainen, M., Paulin, L., Tynkkynen, S., von Ossowski, I.V., Reunanen, J., Partanen, P., Satokari, R., Vesterlund, S., Hendrickx, A.P.A., Lebeer, S., Keersmaecker, S.C.J.D., Vanderleyden, J., Hamalainen, T., Laukkanen, S., Salovuori, N., Ritari, J., Alatalo, E. Korpela, R., Mattila-Sandholm, T., Lassig, A., Hatakka, K., Kinnunen, K.T., Karjalainen, H., Saxelin, M., Laakso, K., Surakka, A., Palva, A., Salusjarvi, T., Auvinen, P., de Vos, W.M., 2009. Comparative genomic analysis of Lactobacillus rhamnosus GG reveals pili containing a human-mucus binding protein. Proc. Natl. Acad. Sci. U. S. A. 106 17193-17198.

Khalil, N.G., 1997. Incidence of Bacillus cereus in some food stuffs with special reference to its production of thermonuclease enzyme in Assiut City. Assiut Vet. Med. J. 38, 55-63.
Kort, R., Sybesma, W., 2012. Probiotics for every body. Trends Biotechnol. 30, 613-615. Kotloff, K.L., Nataro, J.P., Blackwelder, W.C., Nasrin, D., Farag, T.H., Panchalingam, S., Wu, Y. Sow, S.O., Sur, D., Breiman, R.F., Faruque, A.S.G., Zaidi, A.K.M., Saha, D., Alonso, P.L., Tamboura, B., Sanogo, D., Onwuchekwa, U., Manna, B., Ramamurthy, T., Kanungo, S., Ochieng, J.B., Omore, R., Oundo, J.O., Hossain, A., Das, S.K., Ahmed, S., Qureshi, S. Quadri, F., Adegbola, R.A., Antonio, M., Hossain, M.J., Akinsola, A., Mandomando, I., Nhampossa, T., Acácio, S., Biswas, K., O'Reilly, C.E., Mintz, E.D., Berkeley, L.Y. Muhsen, K., Sommerfelt, H., Robins-Browne, R.M., Levine, M.M., 2013. Burden and aetiology of diarrhoeal disease in infants and young children in developing countries (the Global Enteric Multicenter Study, GEMS): a prospective, case-control study. Lancet 382, 209-222

Kumbhar, S.B., Ghosh, J.S., Samudre, S.P., 2009. Microbiological analysis of pathogenic organisms in indigenous fermented milk products. Adv. J. Food Sci. Technol. 1, 35-38.

Lu, R., Fasano, S., Madayiputhiya, N., Morin, N.P., Nataro, J., Fasano, A., 2009. Isolation, identification and characterization of small bioactive peptides from Lactobacillus GG conditional media that exert both anti-Gram-negative and Gram-positive bactericidal activity. J. Pediatr. Gastroenterol. Nutr. 49, 23-30.

Makras, L., Triantafyllou, V., Fayol-Messaoudi, D., Adriany, T., Zoumpopoulou, G. Tsakalidou, E., Servin, A., De Vuyst, L., 2006. Kinetic analysis of the antibacterial activity of probiotic lactobacilli towards Salmonella enterica serovar Typhimurium reveals a role for lactic acid and other inhibitory compounds. Res. Microbiol. 157, 241-247.

Marianelli, C., Cifani, N., Pasquali, P., 2010. Evaluation of antimicrobial activity of probiotic bacteria against Salmonella enterica subsp. enterica serovar Typhimurium 1344 in a common medium under different environmental conditions. Res. Microbiol. 161, 673-680.

McMaster, L.D., Kokott, S.A., Reid, S.J., Abratt, V.R., 2005. Use of traditional African fermented beverages as delivery vehicles for Bifidobacterium lactis DSM 10140. Int. J. Food Microbiol. 102, 231-237.

Mhone, T.A., Matope, G., Saidi, P.T., 2011. Aerobic bacterial, coliform, Escherichia coli and Staphylococcus aureus counts of raw and processed milk from selected smallholder dairy farms of Zimbabwe. Int. J. Food Microbiol. 151, 223-228.

Mpofu, A., Linnemann, A.R., Nout, M.J.R., Zwietering, M.H., Smid, E.J., 2014a. Mutandabota, a food product from Zimbabwe: processing, composition and socio-economic aspects. Ecol. Food Nutr. 53, 24-41.

Mpofu, A., Linnemann, A.R., Sybesma, W., Kort, R., Nout, M.J.R., Smid, E.J., 2014b. Development of a locally sustainable functional food based on mutandabota, a traditional food in southern Africa. J. Dairy Sci. 97, 2591-2599.

Mufandaedza, J., Viljoen, B.C., Feresu, S.B., Gadaga, T.H., 2006. Antimicrobial properties of lactic acid bacteria and yeast-LAB cultures isolated from traditional fermented milk against pathogenic Escherichia coli and Salmonella Enteritidis strains. Int. J. Food Microbiol. 108, 147-152.

Mugochi, T., Parawira, W., Mpofu, A., Simango, C., Zvauya, R., 1999. Survival of some species of Salmonella and Shigella in mukumbi, a traditional Zimbabwean wine. Int J. Food Sci. Nutr. 50, 451-455.

Nanu, E., Latha, C., Sunil, B., Prejit, T.M., Venon, K.V., 2007. Quality assurance and public health safety of raw milk at the production point. J. Food Technol. 2, 145-152.

Nour, A.A., Magboul, B.I., Kheiri, N.H., 1980. Chemical composition of baobab fruit (Adansonia digitata L.). Trop. Sci. 22, 383-388.

Nyatoti, V.N., Mtero, S.S., Rukure, G., 1997. Pathogenic Escherichia coli in traditional African weaning foods. Food Control 8, 51-54.

Østlie, H.M., Helland, M., Narvhus, J.A., 2003. Growth and metabolism of selected strains of probiotic bacteria in milk. Int. J. Food Microbiol. 87, 17-27.

Oyarzabal, O.A., Nogueira, M.C.L., Gombas, D.E., 2003. Survival of Escherichia coli 0157:H7, Listeria monocytogenes and Salmonella in juice concentrates. J. Food Prot. 66, 1595-1598.

Parish, M.E., Narciso, J.A., Friedrich, L.M., 1997. Survival of Salmonellae in orange juice J. Food Saf. 17, 273-281.

Rahimi, E., Sepehri, S., Momtaz, H., 2013. Prevalence of Campylobacter species in milk and dairy products in Iran. Rev. Med. Vet. 164, 283-288.

Seeliger, H.P.R., Jones, D., 1986. Genus Listeria. In: Sneath, P.H.A., Mair, N.S., Sharpe, M.E (Eds.), Bergey's Manual of Systematic Bacteriology. Williams and Wilkins, Baltimore, pp. 1235-1245.

Siegman-Igra, Y., Levin, R., Weinberger, M., Golan, Y., Schwartz, D., Samra, Z., 2002. Listeria monocytogenes infection in Israel and review of cases worldwide. Emerg. Infect. Dis. 8, 305-310.

Silva, M., Jacobus, N.V., Deneke, C., Gorbach, S.L., 1987. Antimicrobial substance from a human Lactobacillus strain. Antimicrob. Agents Chemother. 31, 1231-1233.

Simango, C., Rukure, G., 1991. Survival of Campylobacter jejuni and pathogenic Escherichia coli in mahewu, a fermented cereal gruel. Trans. R. Soc. Trop. Med. Hyg. 85, 399-400.

van Tienen, A., Hullegie, Y.M., Hummelen, R., Hemsworth, J., Changalucha, J., Reid, G. 2011. Development of a locally sustainable functional food for people living with HIV in Sub-Saharan Africa: laboratory testing and sensory evaluation. Benefic. Microbes 2, 193-198.

Vertuani, S., Braccioli, E., Buzzoni, V., Manfredini, S., 2002. Antioxidant capacity of Adansonia digitata fruit pulp and leaves. Acta Phytotherapeutica 2, 2-7.

von Ossowski, I., Reunanen, J., Satokari, R., Vesterlund, S., Kankainen, M., Huhtinen, H. Tynkkynen, S., Salminen, S., de Vos, W.M., Palva, A., 2010. Mucosal adhesion properties of the probiotic Lactobacillus rhamnosus GG SpaCBA and SpaFED pilin subunits. Appl. Environ. Microbiol. 76, 2049-2057.

Zimbabwe Ministry of Agriculture, 2001. Report on Postharvest Fruit Handling Practices and Traditional Processing of Indigenous Fruits. Department of Research and Specialist Services, Ministry of Agriculture, Harare, Zimbabwe. 